7

8

9

10

6

\title{
Trophodynamics of Protomyctophum (Myctophidae) in the Scotia Sea
}

(Southern Ocean)

R. A. SAUNDERS ${ }^{* \dagger}$, M. A. COLLINS ${ }^{*}$, P. WARD*, G. STOWASSER ${ }^{*}$, R. SHREEVE*

AND G. A. TARLING*

*British Antarctic Survey, Natural Environment Research Council, High Cross, Madingley

Road, Cambridge, CB3 OET, UK and Government of South Georgia and South Sandwich Islands, Government House, Stanley, Falkland Islands 
This study investigated spatial and temporal patterns in distribution, population structure and diet of Bolin's lanternfish Protomyctophum bolini, Tenison's lanternfish Protomyctophum tenisoni and gaptooth lanternfish Protomyctophum choriodon in the Scotia Sea using data collected by mid-water trawl nets during spring, summer and autumn. Protomyctophum bolini was the most abundant species of the genus encountered throughout the Scotia Sea with the greatest concentrations occurring around the Antarctic Polar Front (APF). This species had a life cycle of $2+$ years, but spatial differences in population structure were apparent as the I-group was absent from all regions south of the APF, suggesting that the species does not recruit in the Scotia Sea. Protomyctophum tenisoni occurred mostly in waters characteristic of the APF and was absent from the southern Scotia Sea. It had a limited and unimodal size range, but there was clear size-related sexual dimorphism with males significantly larger than females. The species had a life cycle of $\sim 2$ years, but the I-group occurred only in regions close to the APF suggesting that recruitment is restricted to these waters. A seasonal southward migration for P. choriodon is likely as the species occurred mostly to the southwest of South Georgia in summer, but extended to the sea-ice sectors in autumn. Protomyctophum choriodon had a life cycle of 4+ years in the Scotia Sea and the population was dominated by age-classes $>3$ years old. Larval stages were absent during the surveys for all species. Diurnal variations in vertical distribution were apparent for all three species. Inter-specific variations in diet were evident, but all species were primarily copepod feeders, with Metridia spp. Rhincalanus gigas and Calanus simillimus generally dominating their prey. Small euphausiids, principally Thysanoessa spp., were also an important component of their diets, particularly for P. choriodon which had the largest body size. The 
37 spatial and temporal variations in diet for both P. bolini and P. tenisoni were broadly

38 consistent with underlying abundance patterns within mesozooplankton community.

39

40 Key words

41

42 Myctophid fish, Protomyctophum, Feeding ecology, Antarctic krill, Copepod, Scotia Sea 
Mesopelagic fish are the most abundant fishes on earth comprising an estimated biomass in excess of 11,000 million tons (Irigoien et al., 2014). They are important conduits in the transfer of energy through oceanic food webs, linking primary consumers to a range of top marine predators, and contribute to the export of carbon from the surface layers to mesopelagic depths through their extensive vertical migrations (Pakhomov et al., 1996; Smith, 2011; Irigoien et al., 2014). These fish therefore play a major role in the function of oceanic ecosystems and biogeochemical cycles around the globe. However, mesopelagic fish remain one of the least studied components of the oceanic ecosystem, with major uncertainties in the most basic aspects of their biology and ecology. Lanternfish, or myctophids (family Myctophidae), are considered to be the dominant mesopelagic fishes in most the world's oceans in terms of diversity and biomass (Gjøsaeter and Kawaguchi, 1980), but little is known of their distribution of abundance, ecology or trophodynamics in all regions in which they occur. Consequently, determining the ecology of myctophids is an important step towards understanding the operation of oceanic ecosystems at a regional and, ultimately, global level.

Myctophids are difficult to sample at an appropriate temporal and spatial resolution, particularly in remote high latitude regions such as the Southern Ocean. This has not only confounded our understanding of all myctophids in these regions, but has limited 
investigations to the most abundant and frequently encountered species (Linkowski, 1985; Greely et al., 1999; Sassa and Kawaguchi, 2005; Dypvik et al., 2012; Pepin, 2013; Saunders et al., 2014). There are many high latitude myctophid species for which virtually nothing is known about their ecology. The genus Protomyctophum has 16 species that occur mostly at high latitudes in all of the world's oceans and all species are examples of understudied myctophids. The majority of information available on this genus refers to general patterns in biogeography and morphology (Hulley, 1981; McGinnis, 1982), with only a few studies reporting information on abundance and vertical distribution for species such as Protomyctophum arcticum (Lütken 1892) (Kawaguchi and Mauchline, 1982; Fock and John, 2006) and bigeye lanternfish Protomyctophum thompsoni (Chapman 1942) (Pearcy et al., 1977; Beamish et al., 1999; Watanabe et al., 1999) in the sub-Arctic, and Bolin's lanternfish Protomyctophum bolini (Fraser-Brunner 1949) in the sub-Antarctic (Piatkowski et al., 1994; Pusch et al., 2004; Collins et al., 2008; Iwami et al., 2011). Furthermore, few studies have detailed information on Protomyctophum population dynamics (Kawaguchi and Mauchline, 1982), or trophodynamics (Oven et al., 1990; Pakhomov et al., 1996; Pusch et al., 2004;

Sassa and Kawaguchi, 2005; Shreeve et al., 2009) in any region, and those that exist are spatially and temporally limited, often with small sample sizes. There is a clear need for new data on all species within this genus, including the rarer ones, in order to resolve the composition and dynamics of the high latitude mesopelagic fish community. The majority of Protomyctophum species (10 out of 16 species) are found in the Southern 
Protomyctophum choriodon (Hulley 1981) and Tenison's lanternfish Protomyctophum tenisoni (Norman 1930) (Hulley, 1981). The Scotia Sea (Atlantic sector) is one the most productive regions of Southern Ocean, sustaining high levels of secondary production, which in turn supports major populations of whales, seals, penguins and commercially-targeted fish (Atkinson et al., 2001; Holm-Hansen et al., 2004). In this region, myctophids, including the Protomyctophum species, play an important role in the transfer of energy through the food web as they consume herbivorous and omnivorous zooplankton, such as copepods and euphausiids (including Antarctic krill, Euphausia superba) (Pakhomov et al., 1996; Pusch et al., 2004; Shreeve et al., 2009), and are preyed upon by several top marine predators, including seals (e.g. Arctocephalus gazella, Mirounga leonina), penguins (Aptenodytes patagonicus), squid (Martialia hyadesi) and large pelagic fish (Dissostichus eleginoides) (Rodhouse et al., 1992; Olsson and North, 1997; Brown et al., 1999; Cherel et al., 2002; Reid et al., 2006; Collins et al., 2007). Myctophids comprise an estimated biomass of 4.5 million tonnes in the Scotia Sea (Collins et al., 2012), providing a major krill-independent trophic pathway in the usually krill-dominated food web (Murphy et al., 2007b). More comprehensive data on the ecology of all myctophid species in this region is required in light of recent evidence of ocean-warming (Whitehouse et al., 2008), reductions in winter sea-ice extent, (de la Mare, 1997; Curran et al., 2003) and declining krill stocks in the Scotia Sea (Atkinson et al., 2004; Hill et al., 2013), which could have an adverse impact on the Southern Ocean ecosystem (Moline et al., 2004; Murphy et al., 2007a; Flores et al., 2012). With further long-term reductions in krill abundance, as predicted (Hill et al., 2013), the importance of myctophids as a krill-independent trophic pathway is likely to increase in the region. Acquisition of new data on the distribution of abundance, population dynamics and 
feeding ecology of all myctophids is therefore essential for understanding how pelagic food webs are structured in the Scotia Sea, for determining their sensitivity to ongoing environmental change, and for establishing effective ecosystem-based management strategies throughout the Southern Ocean (Kock et al., 2012).

In this paper we present new data on the distribution of abundance, population structure and diet of, P. bolini, P. choriodon and P. tenisoni, in the Scotia Sea. An index of relative importance (IRI), which combines prey occurrence, biomass and numbers, was used to investigate spatial, temporal and ontogenetic variations in their respective diets. Our data were derived from depth-discrete net samples collected between the ice-edge and Antarctic Polar Front (APF) during austral spring, summer and autumn (2006-2009), and are the most comprehensive for the Protomyctophum genus in any region of the world to date. Our study provides important parameterizations for new food web and ecosystem studies in the Scotia Sea that are required in order to cast new light on the potential impacts of ocean-climate change on the operation of the Southern Ocean pelagic food webs and ecosystems. They also contribute to resolving the composition and dynamics of the global mesopelagic fish community.

\section{MATERIALS AND METHODS}

STUDY LOCATION 
131 Oceanographic, acoustic and biological data were collected at stations across the Scotia Sea

132 during three cruises on the RRS James Clark Ross (Fielding et al., 2012; Korb et al., 2012;

133 Venables et al., 2012; Ward et al., 2012; Whitehouse et al., 2012). JR161 was undertaken in

134 November 2006 (spring), JR177 in January 2008 (summer) and JR200 in March 2009

135 (autumn). Dependent on ice and weather conditions, six regional locations were sampled

136 during the surveys: Southern Scotia Sea (SSS), Mid Scotia Sea (MSS), Western Scotia Sea

137 (WSS), Northern Scotia Sea (NSS), Georgia Basin (GB) and the Polar Front (PF) (Fig. 1).

138 Stations were spread across the predominant water masses and frontal zones that occur in the 139 region (Rintoul et al., 2001).

\section{NET SAMPLE COLLECTION AND PROCESSING}

Mesopelagic fish were collected using a Rectangular Midwater Trawl net (RMT25;

Piatkowski et al., 1994) that comprised two opening and closing nets with a $5 \mathrm{~mm}$ mesh at the cod-end. Each net had a flow meter to estimate the filtered water volume and was operated by an electronic downwire net monitoring system that also provided real-time

147 information on depth, temperature and salinity. At each station, depth-stratified hauls were undertaken at 0-200 m, 201-400 m, 401-700 m and 701-1000 m, with the net towed at 2.5 knots for 30-60 mins in each depth zone. These zones were repeated by day and by night during JR161 and JR177, but sampling was only conducted during hours of darkness on 
JR200. The RMT25 was deployed twice in succession to cover the four depth zones at each station, with the upper nets (0-200 and 200-400 m) undertaken as close to local midday or midnight as practical. The majority of nets were deployed in oceanic regions where bottom depths exceeded $1500 \mathrm{~m}$ (see Collins et al. 2012). Additional targeted net hauls were undertaken on acoustically detected fish aggreations during the surveys, mostly around the Polar Front. These hauls were not used to generate estimates of abundance or biomass. Net samples were sorted onboard to the lowest taxonomic level possible (Hulley, 1990) and total catch weights per fish species were recorded using a motion-compensated balance. The standard length (SL) of all fish were measured to the nearest $\mathrm{mm}$. Where possible, sex and maturity status was recorded for a subsample. Stomachs were dissected from a random subsample of 25 fish per non-targeted haul, or from each fish where catches were small. All stomachs were frozen for subsequent microscopic analysis.

\section{STOMACH CONTENTS ANALYSIS}

Fish stomachs contents were sorted to the lowest taxonomic level possible, subject to the state of digestion, following Shreeve et al. (2009). Individual prey items were enumerated and weighed. If the prey was highly disaggregated, the weights of the component species were estimated as a proportion of the total weight of all components.. 
172 Diet was expressed as percentage frequency of occurrence $(\% \mathrm{~F})$, percentage mass $(\% \mathrm{M})$, 173 percentage number $(\% \mathrm{~N})$ and percentage Index of Relative Importance (\%IRI) (Hynes, 1950;

174 Pinkas et al., 1971; Hyslop, 1980; Cortes, 1997). The \%IRI was calculated for prey species

175 and \%IRI $I_{D C}$ for prey categories (Main et al., 2009). In the preliminary analysis, prey

176 categories were defined as: Amphipoda, Copepoda, Euphausiacea, Chordata, Ostracoda and

177 Unidentified crustacean, but a more detailed analysis was subsequently performed using the

178 following nine dominant prey categories: the copepods Metridia spp., Rhincalanus gigas,

179 Pleuromamma robusta, Paraeuchaeta spp., and Calanus simillimus, Other copepods, the

180 euphausiid Thysanoessa spp., the amphipod Themisto gaudichaudii and Other taxa (other

181 amphipods, E. superba, Ostracods, Chordates and unidentified crustaceans). Note that the

\%IRI is not additive so the sum of the individual species' \%IRI is not the same as the prey category \%IRI $I_{D C}$ value (Hansson, 1998). The \%IRI was calculated as:

$\% I R I_{i}=\frac{\left(\% N_{i}+\% M_{i}\right) \times \% F_{i}}{\sum_{i=1}^{n}\left(\% N_{i}+\% M_{i}\right) \times \% F_{i}} \times 100$

where $i$ is prey item.

The \%IRI for each prey category was calculated in this way for all three myctophid species to examine variations in diet between fish pooled by region, season (cruise), size and sex (Table I). For spatial comparisons of diet, data were pooled for regions south of the South Antarctic Circumpolar Current Front (SACCF; stations: SSS and MSS), between the SACCF and the 
193 Southern Boundary of the Antarctic Polar Front (S-APF; stations WSS, NSS, GB) and north 194 of the S-APF (stations: PF) (Fig.1.) Data were also pooled for size-classes less than or greater

195 than the overall population mean for comparisons of each species' diet by size. The $\pm 95 \%$

196 confidence limits for the mean \%IRI of each prey category were calculated using a

197 bootstrapping procedure that re-sampled (with replacement) each species' datasets

198 (individual stomachs) 1000 times (Main et al., 2009).

\section{LENGTH-FREQUENCY ANALYSIS}

201

202 Due to the relatively low sample sizes per species at each station ( $<50$ individuals $)$, it was not possible to investigate spatial variations in length-frequency distributions robustly during the three surveys. Data were therefore pooled by survey for each species to give composite length-frequency distributions for the study region as a whole. CMIX component fitting software (de la Mare, 1994) was then used to fit normal distributions to the composite length-

207 frequency data and identify modes following the approach detailed in Saunders et al. (2007).

208 A series of runs were performed during the analysis based on the presence of one, two or three cohorts in the data and we then determined the best component fit to the observed data using a Chi-squared test. No constraints were placed on the mean length, variance or

211 proportions expected within each component when fitting the mixed distributions.

212 Differences between gender sizes and depth zones were investigated using Students t-tests performed on data aggregated across all surveys. 
215 RESULTS

216

217

OCEANOGRAPHIC CONTEXT

218

219 Detailed descriptions of the oceanographic regime are given in Venables et al. (2012) and

220 Whitehouse et al. (2012), so only a brief overview is given here. During each cruise, stations

221 in the SSS were situated south of the Southern Boundary in the colder waters of the Seasonal

222 Ice Zone. Stations in the WSS and MSS lay close to the South Antarctic Circumpolar Front

223 (SACCF) and had relatively similar water mass properties. The NSS station showed

224 characteristics of the southern edge of the Antarctic Polar Front (APF), particularly during

225 JR161. The GB station, situated downstream of South Georgia, had water mass properties

226 that were more similar to those in the middle of the Scotia Sea than the NSS, primarily due to

227 a retroflection of the flow of the SACCF. The northernmost PF stations were situated north of

228 the southern edge of the APF where surface water temperatures were warmer than those in

229 regions further south.

230

231

DISTRIBUTION

232 
233 A total of 143 RMT25 non-targeted net hauls (i.e. hauls not directed at acoustical targets)

234 were undertaken during the three surveys. Weather and operational constraints meant that it

235 was not possible to sample all stations to the same degree on all surveys. Most notably,

236 sampling at the WSS station was mostly confined to the spring survey.

Several species of Protomyctophum were encountered during the surveys, including

Andriashev's lanternfish Protomyctophum andriashevi (Becker 1963), P. tenisoni, P. bolini,

P. choriodon, parallel lanternfish Protomyctophum parallelum (Lönnberg 1905) and jewelled lanternfish Protomyctophum gemmatum (Hulley 1981) (Fig. 1). Protomyctophum bolini was the most abundant species on each survey, comprising an overall mean abundance of 0.038 -

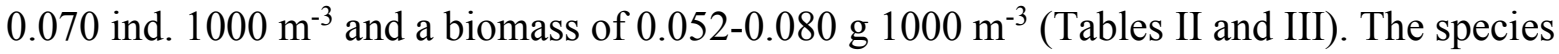
was distributed throughout the Scotia Sea in regions north of the seasonal ice-edge and the greatest concentrations occurred at the PF and GB stations (Fig. 1). Protomyctophum tenisoni was absent from non-targeted net hauls during the summer survey, but comprised a relatively high proportion of abundance during spring and autumn (0.012-0.021 ind. $\left.1000 \mathrm{~m}^{-3}\right)$, particularly around the PF (Fig. 1; Table II). This species was seldom encountered south of

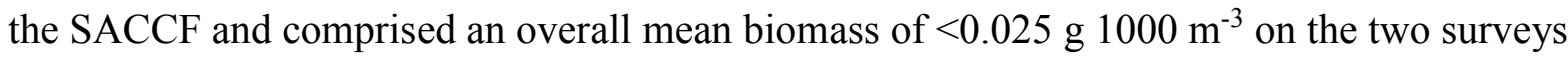
(Table III). Protomyctophum choriodon was absent in spring and was caught predominantly around the GB in summer (Fig. 1). However, it occurred at all stations further south during autumn, with the greatest concentrations generally in the SSS (Table II). The species had an

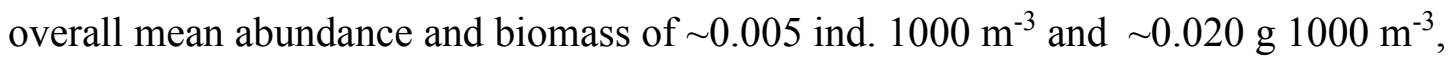
respectively (Tables II and III). Protomyctophum parallelum, $P$. andriashevi and $P$. 
gemmatum were caught predominantly in APF waters during the spring survey. Overall, these species comprised a relatively low abundance and biomass in the Scotia Sea $(<0.050$ ind.

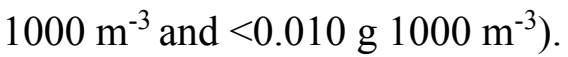

\section{VERTICAL DISTRIBUTION}

The vertical distribution patterns of $P$. bolini, $P$. tenisoni and $P$. choriodon did not differ between seasons or stations, so the data were aggregated to illustrate their overall depth distributions in the region. Daytime catches of $P$. bolini were low and the species was mostly spread between 201-700 m during this time (Fig. 2a). Protomyctophum bolini abundance and biomass was substantially larger at night, where the species occurred higher in the water column between 201-400 m. Only a few individuals were encountered above $200 \mathrm{~m}$ at night. Daytime catches of $P$. tenisoni were also comparatively low and the species was distributed mostly between 401-700 m (Fig. 2b). At night, both mean density and biomass increased markedly and the species occurred solely in the upper $200 \mathrm{~m}$ of the water column, indicative of some diurnal vertical migration (DVM). Protomyctophum choriodon was distributed predominantly between 0-200 m during both day and night, although the species was also present in deeper regions (201-400 m) during the night, but not during the daytime (Fig. 2c). This suggests a night-time deepening of part of the population for this species. Of the other Protomyctophum species encountered on the surveys, $P$. parallelum and P. gemmatum were 
caught exclusively between 400 and $700 \mathrm{~m}$, whilst $P$. andriashevi was predominantly distributed between 200-400 $\mathrm{m}$.

\section{POPULATION SIZE STRUCTURE}

The information available for Protomyctophum species indicate that spawning occurs in spring (September/October) (Oven et al., 1990). The following terminology was therefore adopted to describe the population structure of these myctophids: 0-group covers the period from hatching until 31 October the following year; I-group covers the period 1 November to 31 October the next year; II-group covers the subsequent period from 1 November until 31 October, and so on. Differentiation between the 0-goup and I-group in the population was aided by comparisons of modal size, relative to the estimated spawning period, with published growth rates of high latitude and temperate myctophids (Smoker and Pearcy, 1970; Gjøsaeter, 1978; Linkowski, 1985; Greely et al., 1999). Although the data were collected without temporal repetition in non-consecutive seasons, and therefore interannual effects cannot be accounted for, our analyses provide the most comprehensive synopsis of seasonal variations in Protomyctophum population structure to date.

Length-frequency histograms for $P$. bolini showed one size-, and presumably age-, class in the spring population that we assumed to be the newly recruited II-group containing $\sim 2$ year old individuals based on realistic rates of growth (mode: $50 \mathrm{~mm}$; Fig 3a). Both the newly 
spawned 0-group and I-group were absent during this time. Approximately 5\% of the IIgroup was juvenile and all adults had developing gonads. There was little evidence of growth of the II-group during the summer period (mode: $50 \mathrm{~mm}$ ), indicating that it had attained its terminal size prior to this season. The 0-group and I-group remained absent from the population at this time, and the maturity structure of the II-group was very similar to that in spring. By autumn, the I-group ( 1 year olds) was evident in the population (mode: $38 \mathrm{~mm}$ ), together with the II-group that had reduced in magnitude from the previous season (mode: 51 $\mathrm{mm})$. Juvenile stages dominated the I-group during the autumn and this cohort occurred entirely at the PF and NSS stations, where water masses properties were characteristic of the APF (Fig. 4a). This cohort would presumably overwinter and recruit into the new II-group the following spring, indicating either increased growth rates during the overwinter period or an influx of large fish into the population from other regions prior to spring. The remaining II-group present in the autumn population either died out of the population, or became indistinguishable in size from I-group individuals during the overwintering period, suggesting that the species has a life span of at least two years.

Protomyctophum tenisoni had a limited size range of 30-55 $\mathrm{mm}$ during the surveys and appeared to have a life cycle of approximately two years (Fig. 3b). Only one cohort was present in the population during each survey and the 0-group was consistently absent. In spring, only the newly recruited II-group ( $\sim 2$ yrs olds, mode: $53 \mathrm{~mm})$ was evident in the overwintered population and all individuals within this group were adults with developing gonads. This age-group appeared to have died out by the summer period, as there was no 
overlap of generations. The new I-group ( $\sim 1$ year olds) was first evident in the summer population (mode: $36 \mathrm{~mm}$ ) during target-hauls at the PF (Fig. 4b). Approximately 23\% of this group were juvenile, whilst $\sim 76 \%$ of adults had immature gonads and the remainder had developing gonads. The I-group had increased in size by autumn (mode: $44 \mathrm{~mm}$ ) and would presumably grow and recruit into the II-group the following October. All specimens were adult at this time.

The overall size range of $P$. choriodon during the study was $55-85 \mathrm{~mm}$ and the species had a life cycle of at least four years (Fig. 3c). The composite length-frequency histograms indicated two size-classes in the population during the summer, the III-group ( $\sim 3$ year olds, mode: $70 \mathrm{~mm}$ ) and the IV-group ( 4 year olds, mode: $82 \mathrm{~mm}$ ). No juvenile stages were present at this time and all adults had developing gonads. Too few samples were obtained in autumn to analyse the population structure robustly, but the available data suggest that both III- and IV-group specimens were present at this time. The 0-group, I-group and II-group were consistently absent during the surveys.

Population analyses were not possible for P. parallelum, P. andriashevi and P. gemmatum due to insufficient length-frequency data $(n<30)$. The size ranges for these three species was 29-53, 44-53 and 54-66 mm, respectively.

\section{GENDER-BASED DIFFERENCES}


340 There was no significant $(t$-test, $T=-0.52$, d.f. $=369, P>0.05)$ difference in size between

341 adult $P$. bolini females and males and both sexes had a mean size of $\sim 48 \mathrm{~mm}$. The ratio of

342 females to males was close to 2:1 for this species at all stations across the Scotia Sea.

343 Protomyctophum tenisoni males were slightly, but significantly $(t$-test, $T=-3.32$, d.f. $=111$,

$344 P<0.01$ ) larger than females (means: $43.3 \mathrm{~mm}$ compared to $39.4 \mathrm{~mm}$ ), and the ratio of

345 females to males was approximately 1:1 in all regions. The number of observations for $P$.

346 choriodon was relatively low, but no significant difference $(t$-test, $T=-0.10$, d.f. $=37, P>$

347 0.05) in size between males and females was evident from the available data. Both sexes had

348 a mean size of $\sim 69 \mathrm{~mm}$ and the ratio of females to males was consistently around 1:1.

DIET COMPOSITION

351

352

A total of 231, 46 and 37 stomachs were examined for $P$. bolini, $P$. tenisoni and $P$. choriodon, respectively (Table IV). Protomyctophum bolini had a diet that was dominated by copepods (94\% IRI), with Metridia spp. (59\% IRI), R. gigas (36\%IR) and Paraeuchaeta spp. (4\% IRI) the most predated species. Euphausiids, primarily Thysanoessa spp. (5\% IRI), also comprised an important component of the species' diet. The diet of $P$. tenisoni was similarly dominated by copepods (90\% IRI) and the euphausiid Thysanoessa spp. (10\% IRI), although C. simillimus (71\% IRI) was a major dietary component, with smaller quantities of Metridia spp. (7\% IRI) and $R$. gigas (6\% IRI). The diet of $P$. choriodon largely incorporated these 
same prey species, although much greater proportions of Thysanoessa spp. (42\% IRI) and fewer copepods (63\% IRI) were consumed. Protomyctophum choriodon also preyed upon the amphipod T. gaudichaudii. None of the three Protomyctophum species consumed significant quantities of E. superba.

\section{DIET PATTERNS}

The available data suggested spatial variation in diet for both $P$. bolini (Fig. 5a) and $P$. tenisoni (Fig. 5b). The diet of P. bolini was dominated by Metridia spp. in regions south of the SACCF, but there was a decrease in predation upon these copepods with decreasing latitude towards the PF. Conversely, there was an increase in $R$. gigas predation along this latitudinal gradient. Protomyctophum bolini also seldom preyed upon other copepods and Thysanoessa spp. in the southernmost regions of the Scotia Sea, and predation on Paraeuchaeta spp. occurred predominantly between the SACCF and the S-APF. The diet of P. tenisoni was dominated by $C$. simillimus around the APF, but there was an increase in occurrence of other prey items in the diet south of this front, principally Metridia spp., Thysanoessa spp. and R. gigas.

The data also suggested seasonal variation in the diet of these two myctophids. In spring, the diet of $P$. bolini was dominated by $R$. gigas, but there was a clear reduction in the proportion of this copepod in the diet in summer and autumn (Fig. 6a). Metridia spp. increased in the 
381

382

383

384

385

386

387

388

389

390

391

392

393

394

395

396

397

398

399

400

401

species' diet between spring and autumn and predation on Paraeuchaeta spp. and Thysanoessa spp. was highest in summer. No stomach samples were obtained for P. tenisoni during summer, but there was a clear switch in prey from Thysanoessa spp., R. gigas, Metridia spp. and other copepods, in spring to predominantly C. simillimus in autumn (Fig $6 b)$.

Gender-based variations in diet were not apparent for P. bolini, P. tenisoni, or P. choriodon, and there was no evidence of size-related variations in diet for any of the three species from the available data.

\section{DISCUSSION}

This study, which surveyed the Scotia Sea from the ice-edge to the Antarctic Polar Front in different seasons, provides important information on the distribution, population structure and feeding ecology of P. bolini, P. tenisoni and P. choriodon in the Southern Ocean. Myctophid fish are difficult to sample at high latitudes and their abundance, distribution and population dynamics are inherently patchy and highly variable in space and time. Considering that the data presented here were collected at a relatively low temporal and spatial resolution, and without seasonal replication, such variability needs to be taken into account when interpreting the results of this investigation. The relatively small sample sizes should also be taken into consideration when interpreting the spatial and temporal patterns in diet, particularly for $P$. 
tenisoni. Our data are, however, the best available to date and the results suggest that these three understudied myctophids exhibit different life history, distribution, and diet patterns in the Scotia Sea.

\section{PROTOMYCTOPHUM BOLINI}

Protomyctophum bolini was the most abundant of the three Protomyctophum species in this study and the greatest concentrations of biomass and abundance were found north of the SACCF in the northern Scotia Sea. Protomyctophum bolini is regarded as one of the most common species in the ichthyofauna in the Southern Ocean (Hulley, 1981) and our estimates of abundance/biomass accorded well with those of other studies from the Scotia Sea (Piatkowski et al., 1994; Pusch et al., 2004; Collins et al., 2008). The species has been described as having a sub-Antarctic distribution pattern (Hulley, 1981), although relatively high abundances have been previously reported at higher latitudes in the Scotia Sea, including the South Shetland Islands and the Antarctic Peninsula (Pusch et al., 2004; Donnelly and Torres, 2008). In accordance with other studies, $P$. bolini was caught mostly between 200-400 $\mathrm{m}$ and, although there were certain issues with daytime net avoidance, there was some evidence of DVM similar to that observed previously (Hulley, 1981; Piatkowski et al., 1994; Duhamel et al., 2000; Pusch et al., 2004; Collins et al., 2008; Donnelly and Torres, 2008). Seasonal and regional variation in depth distribution was not apparent for the species from the available data, but the possibility of such variation has been indicated from previous 
423 observations in the region (Piatkowski et al., 1994; Collins et al., 2008). Collins et al. (2012)

424 noted that the upper limit to species depth distribution at South Georgia was consistent with

425 the depth at which the base of the cold Winter Water layer occurred and hypothesised that

426 temperature is an important control on its vertical distribution. A similar trend seemed

427 apparent at the Antarctic Peninsula (Donnelly and Torres, 2008).

The data indicated that $P$. bolini had a life cycle of approximately two years in the Scotia Sea.

The species attained a maximum size of around $70 \mathrm{~mm}$ and there was no evidence of sizerelated sexual dimorphism, which is consistent with other studies (Collins et al., 2008).

During the study, there was a marked absence of newly spawned larvae and the 0-group component of the population from all biological samplers (including Longhurst-Hardy

Plankton Recorder, RMT8 nets and Bongo nets) suggesting that recruitment for the species year olds) were present in regions further south. This supports the notion that this predominantly sub-Antarctic species only completes its life cycle in waters north of the APF and that there is a distinct spatial separation in population structure between the Subtropical Front (STF) and the Scotia Sea (Hulley, 1981; Pusch et al., 2004; Collins et al., 2008). It has been suggested that the adults of this species migrate south of the APF to feed in the Scotia

442 Sea, leaving the juvenile component of the population in waters to the north of this front 443 (Hulley, 1981; Collins et al., 2008). Similar patterns in behaviour have been suggested for myctophids in the sub-Arctic (Sassa and Kawaguchi, 2005). However, it is also possible that 
spawning, recruitment and sexual development are inhibited in the colder waters of the Scotia

446 Sea and the population structure in the Scotia Sea reflects an expatriate population.

447 Protomyctophum eggs, for example, have only been observed in regions north of the APF

448 (Efremenko, 1986), suggesting that the cold waters of the Scotia Sea may inhibit egg 449 survival.

Protomyctophum bolini fed mostly on copepods, particularly Metridia spp., and R. gigas,

which is in accordance with previous observations in the Scotia Sea (Pusch et al., 2004).

Other studies have reported that the species feeds primarily on small euphausiids, but these conclusions were based on relatively low sample sizes (Gaskett et al., 2001; Shreeve et al., 2009). Spatial variation in diet was indicated for $P$. bolini, which broadly reflected the regional availability of the main prey species in the mesozooplankton community across the Scotia Sea (Ward et al., 2012). For example, predation on all copepods species other than Metridia spp. was highest in regions north of the SACCF where their abundance was markedly higher than that south of this front. The reduced availability of these copepods south of the SACCF may therefore have resulted in the switch to predominantly Metridia spp. predation in the region. The apparent seasonal variation in diet did not reflect the overall seasonal pattern in copepod abundance, as the abundance of most prey-species north of the SACCF was relatively similar across surveys (Ward et al., 2012). However, there was a tendency for older copepodite stages of $R$. gigas to be present in the region during spring, which, may account for some of the observed seasonal changes in diet. Shreeve et al. (2009) observed that myctophids tend to target the older copepodite stages, particularly adult 
467 females. The switch from $R$. gigas predation in spring to predation on other copepods in 468 summer and autumn may therefore have been related to a reduction in the availability of 469 older R. gigas stages in the prey field. Differences in copepod behaviour, such as DVM, 470 reactivity to stimuli and seasonal diapause may also be important factors in temporal and 471 ontogenetic variations in myctophid predation (Shreeve et al., 2009).

Protomyctophum tenisoni is a particularly understudied species throughout the Southern

Ocean and, prior to this investigation, most aspects of the species' distribution, population

477 dynamics and trophic ecology were unknown, particularly in the Scotia Sea. In this study, $P$. tenisoni was relatively abundant during the spring and autumn surveys and it was primarily found near the APF. The species did not occur south of the SACCF, which agrees with other observations that indicate that $P$. tenisoni is a predominantly sub-Antarctic species, with a southern distributional limit around the Antarctic Convergence $\left(\sim 60^{\circ} \mathrm{S}\right)$ (Hulley, 1981 ; McGinnis, 1982). Our data showed that the species was distributed below $400 \mathrm{~m}$ during the daytime, but moved up the water column to layers above $200 \mathrm{~m}$ at night, indicative of DVM behaviour, and consistent with observations around the Kerguelen Islands (Indian sector)

485 (Duhamel et al., 2000). 
487

488

489

490

491

492

493

494

495

496

497

498

499

500

501

502

503

504

505

Protomyctophum tenisoni had a limited size range throughout the Scotia Sea, but there was evidence of size-related sexual dimorphism that, to our knowledge, has not been previously reported for a species within this genus (Collins et al., 2008). Unlike many myctophid species, such as Antarctic lanternfish Electrona antarctica (Günther 1878), Carlsberg’s lanterfish Electrona carlsbergi (Tåning 1932) and Brauer’s lanterfish Gymnoscopelus braueri (Lönnberg 1905) (Rowedder, 1979; Collins et al., 2008), P. tenisoni males were larger in size than females suggesting that selection mechanisms in growth and life history strategies could differ between the sexes in this species (Parker, 1992)..

Our data also indicated that $P$. tenisoni had a life cycle of approximately two years and that recruitment appeared to be confined to regions north of the APF, as evidenced by a marked absence of larval stages and the 0 -group during the surveys. Furthermore, I-group specimens were absent in the Scotia Sea in all seasons. These trends are consistent with the notion that P. tenisoni is a predominantly sub-Antarctic species, which spawns in regions towards the STF, and that either ontogenetic migrations, or expatriate effects may be an important control on spatial patterns in population structure. It has been reported that $P$. tenisoni reaches sexual maturity at $\sim 41 \mathrm{~mm}$ and attains a maximum size of around $54 \mathrm{~mm}$ (Hulley, 1981), which is consistent with our findings. Our data suggested that cohort growth rates of $P$. tenisoni were similar to that of $P$. bolini, although the species appears to spawn slightly earlier. 
Protomyctophum tenisoni fed mostly upon copepods, with $C$. simillimus dominating this

508

509

510

511

512

513

514

515

516

517

518

519

520

521

522

523

524

525

526

527

528

component of the prey field. Small euphausiids of the Thysanoessa genus also comprised an important part of the diet. To our knowledge, the only other data available on the trophodynamics of P. tenisoni are from a study at Macquarie Island (Pacific sector of the Southern Ocean), which reported that the species was predominantly a copepod feeder, but also took high proportions of euphausiids and amphipods. However, information on prey species composition was not detailed in that study and, similar to the present study, the sample size was relatively low (Gaskett et al., 2001). The diet of $P$. tenisoni appeared to vary between the APF and regions further south from the available data collected during our study and this corresponded broadly with spatial changes in the abundance of the main prey species (Ward et al., 2012). Data from the concurrent mesozooplankton survey showed that $C$. simillimus abundance was markedly higher at the PF stations than at those between the SACCF and S-PF, whilst the abundance of prey species such as Metridia spp., R. gigas, and Thysanoessa spp. was comparatively lower. Thus $P$. tenisoni appeared to prey upon $C$. simillimus in regions where its availability was highest, but then switched to other prey items in regions where these species became increasingly abundant and the availability of $C$. simillimus was reduced. However, it is also possible that seasonal effects could have contributed to the apparent regional pattern in diet, as P. tenisoni stomachs were mostly obtained at the PF front in autumn, during which time its diet was almost exclusively comprised of C. simillimus. Further data are clearly warranted to substantiate spatial and temporal trends inthe diet of this rarer myctophid species, and to examine the possibility of ontogenetic variations in its diet robustly. 
532 Protomyctophum choriodon was caught only on the summer and autumn surveys, but the

533 available data suggest the possibility of a seasonal southward migration for the species.

534 During the summer survey, $P$. choriodon occurred exclusively at the GB stations to the northwest of South Georgia, but the species was distributed in regions further south in autumn. Although P. choriodon is regarded as a sub-Antarctic species that is usually associated with the APF and regions further north (Hulley, 1981), the species occurs regularly in fur seal (Arctocephalus gazella) diets at South Georgia in late summer and autumn (Reid et al., 2006). The abundance of P. choriodon in fur seal diet samples is also strongly correlated with sea-surface temperature (Reid et al., 2006), supporting the idea that it undertakes seasonal migrations to regions south of the APF during periods of elevated seasurface temperatures (Collins et al., 2012). Alternatively, the seasonal increase in water temperatures may simply enable the species to survive temporarily at higher latitudes and expansion of its southern distributional range might not be a function of behaviour-specific migrations per se.

547 During the study, $P$. choriodon was caught primarily above $400 \mathrm{~m}$, with the species 548 distributed exclusively between 0-200 m during the day and peak concentrations also 549 occurring in this zone at night. These observations are consistent with those at South Georgia, although the species was predominantly distributed between $200-400 \mathrm{~m}$ during the daytime in 
this region, but occasional daytime catches have been made at depths of $\sim 150 \mathrm{~m}$ (Collins et al., 2008). Acoustic studies have further reported that myctophid schools are not uncommon above $200 \mathrm{~m}$ in the Scotia Sea during the daytime, particularly in off-shelf regions where they can occur in the near-surface zone (Fielding et al., 2012; Saunders et al., 2013). Our data also indicated a downward movement of part of the population at night, which could be a sinking response following satiation after night-time feeding (Tarling and Johnson, 2006), or an ontogenetic separation of the population that was not detected in the study due to the relatively low sample sizes.

Population analyses were limited for P. choriodon due to its absence in spring and relatively low sample sizes in summer and autumn. However, the available data suggested that the species had a life cycle of at least four years. Other studies have reported that $P$. choriodon reaches sexual maturity at $\sim 77 \mathrm{~mm}$, attains a maximum size of $95 \mathrm{~mm}$ and spawns once in spring during its life cycle (Hulley, 1981; Oven et al., 1990). An ontogenetic separation in the population was suggested for the species, as specimens towards the STF tended to be juveniles whereas mature adults were more prevalent in regions closer to the Scotia Sea (Hulley, 1981). Collins et al. (2008) also observed a unimodal population structure of limited size range (60-75 $\mathrm{mm})$ at South Georgia during autumn and further hypothesised that the species does not complete its life cycle south of the APF. These notions were supported by our study as (i) there was no evidence of spawning in the study region, (ii) there was a distinct absence of 0- and I-group specimens and (iii) the population was dominated by older year-classes ( $>3$ year old). Similar to $P$. bolini and $P$. tenisoni, this suggests that either the 
573

574 from the younger stages that reside north of the APF to the Scotia Sea, or that the species is

575 an expatriate in the Scotia Sea.

576

577 Although our sample size was relatively low, the diet of $P$. choriodon was broadly consistent

579

580

581

582

583

584

585

586

587

588

589

590

591

592

593

species undertakes a stage-specific migration whereby older specimens actively move away with that reported previously in the northern Scotia Sea and this species appears to be mostly a copepod and euphausiid predator (Oven et al., 1990; Shreeve et al., 2009). Euphausiids comprised a greater part of the diet than found in $P$. bolini and $P$. tenisoni and this could be a function of its greater body size that enables it to predate larger prey items more effectively (Karpouzi and Stergiou, 2003). There were too few data to investigate spatial and temporal patterns in diet for this species in this study, although such variation has been suggested from limited data in the region, as $P$. choriodon tended to predate small euphausiids more at higher latitudes (Oven et al., 1990). However, more quantitative data are warranted to substantiate and quantify such trends in this species diet.

\section{PROTOMYCTOPHUM NICHE SEPARATORS}

In pelagic ecosystems, differences in diets, vertical distribution and life cycle strategies are important niche separators that enable several species to co-exist within the same locality (Barange, 1990). The Protomyctophum species studied in this investigation are similar in appearance, have distribution patterns that overlap in the Scotia Sea region, and appear to be 
594

595

596

597

598

599

600

601

602

603

604

605

606

607

608

609

610

611

612

613

614

615

adapted to the sub-Antarctic environment. However, data suggest that these species exhibit different niche roles that may explain how they are able to avoid direct competition for resources and co-exist in the region. For example, $P$. choriodon is a larger-sized species that is able to predate larger prey items, such as euphausiids and amphipods, than either P. bolini or P. tenisoni. Unlike P. bolini and P. tenisoni, P. choriodon appears to reside in the upper $200 \mathrm{~m}$ during the daytime, with part of the population moving to deeper depths of the water column at night. The species may also undertake seasonal southward migrations and has a greater juvenile growth rate than $P$. bolini and $P$. tenisoni, as well as a longer life cycle.

Protomyctophum bolini and P. tenisoni are similarly sized species that exhibit similar rates of growth and have comparable life spans. They are also both predominantly copepod predators. However, $P$. tenisoni appears to spawn slightly earlier than $P$. bolini and they seem to target different copepod species, with P. tenisoni feeding mostly on C. simillimus and P. bolini feeding on Metridia spp. and R. gigas. Both species appear to undertake DVM, but $P$. tenisoni was distributed higher in the water column at night than P. bolini. Protomyctophum bolini also appeared to have a distribution pattern that extended as far south as the sea-ice sector in all seasons, whereas $P$. tenisoni had a distribution pattern that was more closely associated with waters of the APF. These three myctophid species therefore seem to have different niche roles in the Scotia Sea region and do not appear to be in direct competition for resources in regions where they co-occur.

\section{ACKNOWLEDGEMENTS}


616 We thank the officers, crew and scientists of the RRS James Clark Ross for their assistance

617 with the sampling programme during the three surveys. This work was carried out as part of

618 the Ecosystems programme at the British Antarctic Survey, funded by the Natural

619 Environment Research Council. We also thank E. Foster for helping with laboratory work. 
622 Atkinson, A., Siegel, V. \& Rothery, P. (2004). Long-term decline in krill stock and increase in salps 623 within the Southern Ocean. Nature 432, 100-103.

624 Atkinson, A., Whitehouse, M. J., Priddle, J., Cripps, G. C., Ward, P. \& Brandon, M. (2001). South 625 Georgia, Antarctica: a productive, cold water, pelagic ecosystem. Marine Ecology Progress Series $626216,279-308$.

627 Barange, M. (1990). Vertical migration and habitat partitioning of 6 euphausiid species in the North Benguela upwelling system. Journal of Plankton Research 12, 1223-1237. ecology, distribution, and abundance of midwater fishes of the Subarctic Pacific gyres. Progress in Oceanography 43, 399-442.

Brown, D. J., Boyd, I. L., Cripps, G. C. \& Butler, P. J. (1999). Fatty acid signature analysis from the milk of Antarctic fur seals and Southern elephant seals from South Georgia: implications for diet determination. Marine Ecology Progress Series 187, 251-263. at the Falkland Islands, southern Atlantic Ocean. Polar Biology 25, 898-906. 
637 Collins, M. A., Ross, K. A., Belchier, M. \& Reid, K. (2007). Distribution and diet of juvenile Patagonian toothfish on the South Georgia and Shag Rocks Shelves (Southern Ocean). Marine Biology 152, 135147.

640 Collins, M. A., Stowasser, G., Fielding, S., Shreeve, R., Xavier, J. C., Venables, H. J., Enderlein, P.,

641 Cherel, Y. \& Van de Putte, A. (2012). Latitudinal and bathymetric patterns in the distribution and 642 abundance of mesopelagic fish in the Scotia Sea. Deep-Sea Research Part li-Topical Studies in 643 Oceanography 59, 189-198.

644 Collins, M. A., Xavier, J. C., Johnston, N. M., North, A. W., Enderlein, P., Tarling, G. A., Waluda, C. M., 645 Hawker, E. J. \& Cunningham, N. J. (2008). Patterns in the distribution of myctophid fish in the 646 northern Scotia Sea ecosystem. Polar Biology 31, 837-851.

647 Cortes, E. (1997). A critical review of methods of studying fish feeding based on analysis of stomach 648 contents: application to elasmobranch fishes. Canadian Journal of Fisheries and Aquatic Sciences 54, $649 \quad 726-738$.

650 Curran, M. A. J., van Ommen, T. D., Morgan, V. I., Phillips, K. L. \& Palmer, A. S. (2003). Ice core 651 evidence for sea ice decline since the 1950s. Science 302, 1203-1206.

652 de la Mare, W. (1994). Estimating krill recruitment and its variability. CCAMLR Science 1, 55-69.

653 de la Mare, W. K. (1997). Abrupt mid-twentieth-century decline in Antarctic sea ice extent from 654 whaling records. Nature 389, 387-400. 
657 Duhamel, G., Koubbi, P. \& Ravier, C. (2000). Day and night mesopelagic fish assemblages off the 658 Kerguelen Islands (Southern Ocean). Polar Biology 23, 106-112.

659 Dypvik, E., Klevjer, T. A. \& Kaartvedt, S. (2012). Inverse vertical migration and feeding in glacier 660 lanternfish (Benthosema glaciale). Marine Biology 159, 443-453.

661 Efremenko, V. N. (1986). Distribution of eggs and larvae of Myctophidae in the southern Atlantic. 662 Journal of Ichthyology 26, 141-147. determination of the distribution of fish and krill across the Scotia Sea in spring 2006, summer 2008 and autumn 2009. Deep-Sea Research Part li-Topical Studies in Oceanography 59, 173-188. 19. 
672 Fock, H. \& John, H. C. (2006). Fish larval patterns across the Reykjanes Ridge. Marine Biology Research 2, 191-199.

674 Gaskett, A. C., Bulman, C., He, X. \& Goldsworthy, S. D. (2001). Diet composition and guild structure of 675 mesopelagic and bathypelagic fishes near Macquarie Island, Australia. New Zealand Journal of 676 Marine and Freshwater Research 35, 469-476.

677 Gjøsaeter, J. (1978). Age, growth and mortality of the myctophid fish, Benthosema glaciale 678 (Reinhardt), from western Norway. Sarsia 52, 53-58.

679 Gjøsaeter, J. \& Kawaguchi, K. (1980). A review of the world resources of mesopelagic fish. FAO (Food 680 and Agriculture Organization of the United Nations) Fisheries Technical Paper 193, 1-151.

681 Greely, T. M., Gartner, J. V. \& Torres, J. J. (1999). Age and growth of Electrona antarctica (Pisces : 682 Myctophidae), the dominant mesopelagic fish of the Southern Ocean. Marine Biology 133, 145-158. Hansson, S. (1998). Methods of studying fish feeding: a comment. Canadian Journal of Fisheries and 684 Aquatic Sciences 55, 2706-2707. Hill, S. L., Phillips, T. \& Atkinson, A. (2013). Potential climate change effects on the habitat of 686 Antarctic krill in the Weddell quadrant of the Southern Ocean. PloS one 8, 1-12.

687 Holm-Hansen, O., Kahru, M., Hewes, C. D., Kawaguchi, S., Kameda, T., Sushin, V. A., Krasovski, I., 688 Priddle, J., Korb, R., Hewitt, R. P. \& Mitchell, B. G. (2004). Temporal and spatial distribution of 
chlorophyll-a in surface waters of the Scotia Sea as determined by both shipboard measurements and satellite data. Deep-Sea Research Part li-Topical Studies in Oceanography 51, 1323-1331.

Hulley, P. A. (1981). Results of the research cruises of FRV "Walther Herwig" to South America. 58. Family Myctophidae (Osteichthyes, Myctophiformes). Archiv fur Fischereiwissenschaft 31, 1-300.

Hulley, P. A., ed. (1990). Myctophidae. Grahamstown: J.L.B. Smith Institute of Ichthyology.

Hynes, H. B. N. (1950). The food of fresh-water sticklebacks (Gasterosteus aculeatus and Pygosteus pungitius), with a review of the methods used in studies of the food of fishes Journal of Animal Ecology 19, 36-58.

Hyslop, E. J. (1980). Stomach contents analysis: a review of methods and their application. Journal of Fish Biology 17, 411-429.

Irigoien, X., Klevjer, T. A., Rostad, A., Martinez, U., Boyra, G., Acuna, J. L., Bode, A., Echevarria, F., Gonzalez-Gordillo, J. I., Hernandez-Leon, S., Agusti, S., Aksnes, D. L., Duarte, C. M. \& Kaartvedt, S. (2014). Large mesopelagic fishes biomass and trophic efficiency in the open ocean. Nature Communications 5, 3271.

Iwami, T., Naganobu, M., Taki, K. \& Kiyota, M. (2011). Annual changes in species composition and abundance of myctophid fish in the north of South Georgia (Subarea 48.3), Antarctica, during austral winters from 2002 to 2008. CCAMLR Science 18, 155-165. 

length for 18 species of marine fishes and their trophic implications. Journal of Fish Biology 62, 13531365.

Kawaguchi, K. \& Mauchline, J. (1982). Biology of myctophid fishes (Family Myctophidae) in the Rockall Trough, Northeastern Atlantic Ocean. Biological Oceanography 1, 337-374.

711 Kock, K. H., Barrera-Oro, E., Belchier, M., Collins, M. A., Duhamel, G., Hanchet, S., Pshenichnov, L., 712 Welsford, D. \& Williams, R. (2012). The role of fish as predators of krill (Euphausia superba) and 713 other pelagic resources in the Southern Ocean. CCAMLR Science 19, 115-169.

714 Korb, R. E., Whitehouse, M. J., Ward, P., Gordon, M., Venables, H. J. \& Poulton, A. J. (2012). Regional 715 and seasonal differences in microplankton biomass, productivity, and structure across the Scotia 716 Sea: Implications for the export of biogenic carbon. Deep-Sea Research Part li-Topical Studies in 717 Oceanography 59, 67-77.

718 Linkowski, T. B. (1985). Population biology of the myctophid fish Gymnoscopelus nicholsi (Gillber, 719 1911) from the western South Atlantic. Journal of Fish Biology 27, 683-698.

720 Main, C. E., Collins, M. A., Mitchell, R. \& Belchier, M. (2009). Identifying patterns in the diet of 721 mackerel icefish (Champsocephalus gunnari) at South Georgia using bootstrapped confidence 722 intervals of a dietary index. Polar Biology 32, 569-581. 
McGinnis, R. F. (1982). Biogeography of lanternfishes (Myctophidae) south of $30^{\circ} \mathrm{S}$. Washington DC: Amercian Geophysical Union.

725

726

727

728

729

730

731

732

733

734

735

736

737

738

Moline, M. A., Claustre, H., Frazer, T. K., Schofields, O. \& Vernet, M. (2004). Alteration of the food web along the Antarctic Peninsula in response to a regional warming trend. Global Change Biology 10, $1973-1980$.

Murphy, E. J., Trathan, P. N., Watkins, J. L., Reid, K., Meredith, M. P., Forcada, J., Thorpe, S. E., Johnston, N. M. \& Rothery, P. (2007a). Climatically driven fluctuations in Southern Ocean ecosystems. Proceedings of the Royal Society B-Biological Sciences 274, 3057-3067.

Murphy, E. J., Watkins, J. L., Trathan, P. N., Reid, K., Meredith, M. P., Thorpe, S. E., Johnston, N. M., Clarke, A., Tarling, G. A., Collins, M. A., Forcada, J., Shreeve, R. S., Atkinson, A., Korb, R., Whitehouse, M. J., Ward, P., Rodhouse, P. G., Enderlein, P., Hirst, A. G., Martin, A. R., Hill, S. L., Staniland, I. J., Pond, D. W., Briggs, D. R., Cunningham, N. J. \& Fleming, A. H. (2007b). Spatial and temporal operation of the Scotia Sea ecosystem: a review of large-scale links in a krill centred food web. Philosophical Transactions of the Royal Society B-Biological Sciences 362, 113-148.

Olsson, O. \& North, A. W. (1997). Diet of the King Penguin Aptenodytes patagonicus during three summers at South Georgia. Ibis 139, 504-512.

Oven, L. S., Konstantinova, M. P. \& Shevchenko, N. F. (1990). Aspects of of reproduction and feeding of myctophids (Myctophidae) in the southwest Atlantic. Journal of Ichthyology 30, 115-127. 
741 Pakhomov, E. A., Perissinotto, R. \& McQuaid, C. D. (1996). Prey composition and daily rations of 742 myctophid fishes in the Southern Ocean. Marine Ecology Progress Series 134, 1-14.

743 Parker, G. A. (1992). The evolution of sexual size dimorphism in fish. Journal of Fish Biology 41, 1-20.

744 Pearcy, W. G., Krygier, E. E., Mesecar, R. \& Ramsey, F. (1977). Vertical distribution and migration of 745 oceanic micronekton off Oregon. Deep-Sea Research 24, 223-245.

746 Pepin, P. (2013). Distribution and feeding of Benthosema glaciale in the western Labrador Sea: Fish747 zooplankton interaction and the consequence to calanoid copepod populations. Deep-Sea Research 748 Part I-Oceanographic Research Papers 75, 119-134.

749 Piatkowski, U., Rodhouse, P. G., White, M. G., Bone, D. G. \& Symon, C. (1994). Nekton community of 750 the Scotia Sea as sampled by the RMT 25 during austral summer. Marine Ecology Progress Series $751 \quad 112,13-28$. Pinkas, L., Oliphant, M. S. \& Iverson, I. L. K. (1971). Food habits of albacore, bluefin tuna and bonito in California waters. California Department of Fish and Game Fish Bulletin, 3-105. mesopelagic fishes in the slope waters of King George Island (South Shetland Islands, Antarctica). Deep-Sea Research Part I-Oceanographic Research Papers 51, 1685-1708. 
Reid, K., Davis, D. \& Staniland, I. J. (2006). Spatial and temporal variability in the fish diet of Antarctic fur seal (Arctocephalus gazella) in the Atlantic sector of the Southern Ocean. Canadian Journal of Zoology 84, 1025-1037.

760 Rintoul, S. R., Hughes, C. W. \& Olbers, D. (2001). The Antarctic Circumpolar Current System. In Ocean

761 Circulation and Climate (Siedler, C., Church, J. \& Gould, J., eds.), pp. 271-302. London: Academic 762 Press.

763 Rodhouse, P. G., White, M. G. \& Jones, M. R. R. (1992). Trophic relations of the cephalopod Martialia 764 hyadesi (Teuthoidea, Ommastrephidae) at the Antarctic Polar Front, Scotia Sea. Marine Biology 114, $765 \quad 415-421$.

766 Rowedder, U. (1979). Some aspects of the biology of Electrona antarctica (Gunther, 1878) (Family 767 Myctophidae). Meeresforschung 27, 244-251.

768 Sassa, C. \& Kawaguchi, K. (2005). Larval feeding habits of Diaphus theta, Protomyctophum 769 thompsoni, and Tarletonbeania taylori (Pisces : Myctophidae) in the transition region of the western 770 North Pacific. Marine Ecology Progress Series 298, 261-276.

771 Saunders, R. A., Collins, M. A., Foster, E., Shreeve, R. S., Stowasser, G., Ward, P. \& Tarling, G. A. 772 (2014). The trophodynamics of Southern Ocean Electrona (Myctophidae) in the Scotia Sea. Polar 773 Biology 37, 789-807. 
774

775

776

777

778

779

780

781

782

783

784

785

786

787

788

789

790

Saunders, R. A., Fielding, S., Thorpe, S. E. \& Tarling, G. A. (2013). School characteristics of mesopelagic fish at South Georgia. Deep-Sea Research Part I-Oceanographic Research Papers 81, 6277.

Saunders, R. A., Ingvarsdottir, A., Rasmussen, J., Hay, S. J. \& Brierley, A. S. (2007). Regional variation in distribution pattern, population structure and growth rates of Meganyctiphanes norvegica and Thysanoessa longicaudata in the Irminger Sea, North Atlantic. Progress in Oceanography 72, 313342.

Shreeve, R. S., Collins, M. A., Tarling, G. A., Main, C. E., Ward, P. \& Johnston, N. M. (2009). Feeding ecology of myctophid fishes in the northern Scotia Sea. Marine Ecology Progress Series 386, 221-236.

Smith, A. D. M. (2011). Impacts of fishing low-trophic level species on marine ecosystems. Science 333, 1147-1150.

Smoker, W. \& Pearcy, W. G. (1970). Growth and reproduction of the lanternfish Stenobrachius leucopsarus. Journal of the Fisheries Research Board of Canada 27, 1265-1275.

Tarling, G. A. \& Johnson, M. L. (2006). Satiation gives krill that sinking feeling. Current Biology 16, 8384.

Venables, H., Meredith, M. P., Atkinson, A. \& Ward, P. (2012). Fronts and habitat zones in the Scotia Sea. Deep-Sea Research Part li-Topical Studies in Oceanography 59, 14-24. 
791 Ward, P., Atkinson, A. \& Tarling, G. (2012). Mesozooplankton community structure and variability in the Scotia Sea: A seasonal comparison. Deep-Sea Research Part Ii-Topical Studies in Oceanography 59, 78-92.

794 Watanabe, H., Moku, M., Kawaguchi, K., Ishimaru, K. \& Ohno, A. (1999). Diel vertical migration of 795 myctophid fishes (Family Myctophidae) in the transitional waters of the western North Pacific. 796 Fisheries Oceanography 8, 115-127.

797 Whitehouse, M. J., Atkinson, A., Korb, R. E., Venables, H. J., Pond, D. W. \& Gordon, M. (2012). 798 Substantial primary production in the land-remote region of the central and northern Scotia Sea. 799 Deep-Sea Research Part li-Topical Studies in Oceanography 59, 47-56.

800 Whitehouse, M. J., Meredith, M. P., Rothery, P., Atkinson, A., Ward, P. \& Korb, R. E. (2008). Rapid 801 warming of the ocean around South Georgia, Southern Ocean, during the 20th century: Forcings, 802 characteristics and implications for lower trophic levels. Deep-Sea Research Part I-Oceanographic 803 Research Papers 55, 1218-1228. 